\title{
A COMPARATIVE STUDY OF REGENERATED BAMBOO, COTTON AND VISCOSE RAYON FABRICS. PART 1: SELECTED COMFORT PROPERTIES
}

\author{
Adine Gericke* \& Jani van der Pol
}

\section{OPSOMMING}

Geregenereerde bamboes, ook bekend as bamboes viskose, is ' $n$ verwerkte sellulosevesel wat onlangs op die mark verskyn het. Tekstielstowwe van dié vesels is geskik vir ' $n$ verskeidenheid produkte in die klerasie sowel as huishoudelike mark. Die gewildheid daarvan kan toegeskryf word aan die feit dat dit bemark word as omgewingsvriendelik en hernubaar (wat in hierdie geval verwys na die feit dat die bamboes waarvan dit gemaak word ' $n$ rou material is wat baie vinnig groei, nie bedreig is nie en sonder oormatige chemikalieë verbou word). Daar word ook aanspraak gemaak op buitengewone gemakseienskappe wat verband hou met vogabsorbeervermoë en aanvoeling. Dit is ook bekend dat die vesels antimikrobiese eienskappe besit.

Behalwe vir die sogenaamde "cool feeling", is die gemakseienskappe waarna verwys word eintlik van toepassing op die meeste sellulosevesels of tekstielstowwe - veral katoen en viskose rayon. Die gladde filamentstruktuur van viskose rayon lei tot 'n uitstekende drapeervermoë en 'n aanvoeling wat beskryf kan word as "glad en luuks". Hierdie veseleienskappe kan ook aanleiding gee tot " $n$ "koel" sensasie op die vel. Die vraag ontstaan dus of die vermoë om vog te hanteer en die termo-fisiologiese eienskappe van bamboes viskose werklik beter is as dié van ander sellulose- vesels.

Die doel van hierdie studie was om empiries te ondersoek of die voghanteervermoë en termofisiologiese gemakseienskappe van geregenereerde bamboesveselstowwe betekenisvol verskil van dié van katoen en viskose rayon. Objektiewe meetinstrumente is gebruik om eienskappe soos termiese weerstand en absorbeervermoë, waterdampdeurlaatbaarheid, waterabsorbeervermoë en die vogdeurlaatbaarheidsindeks van drie tekstielstowwe, gebrei van garings van onderskeidelik bamboesvesel, katoenen viskose rayon, te vergelyk. Die onderskeie veselstrukture is vergelyk met behulp van ' $n$ skandeer elektronmikroskoop (SEM).

In teenstelling met wat verwag is, is geen empiriese bewyse gevind dat die gemakseienskappe van bamboesveselstowwe beter is as dié van die ander twee sellulosevesels wat getoets is nie. Dit is belangrik om daarop te let dat geen van die aansprake wat gemaak word ten opsigte van genoemde eienskappe as onwaar bewys kon word nie. Bamboesvesels kan beslis verwerk word in produkte wat ' $n$ besondere bydrae lewer tot die versekering van die gemak van die draer omdat dit vog en temperatuur goed kan reguleer. Die resultate van die studie dui egter daarop dat die gebreide katoen en veral die gebreide viskose rayon stowwe wat getoets is, vergelykbare eienskappe toon. Die resultate bevestig ook die verwagting dat metings op die viskose rayon stowwe as gevolg van die ooreenstemming in fisiese veselstruktuur en vervaardigingsprosesse baie meer sou ooreenstem met dié van die bamboesveselstowwe as met dié wat van katoen vervaardig is.

\section{- Ms A Gericke *}

Department of Chemistry and Polymer Science

University of Stellenbosch

E-mail: agericke@sun.ac.za

Tel: +27218083341

Fax: +27218083849

${ }^{*}$ Corresponding author

\section{- Ms J van der Pol}

Department of Chemistry and Polymer Science University of Stellenbosch

ACKNOWLEDGEMENTS: The authors would like to thank Prof Lubos Hes and the Department of Textile Science, Technical University of Liberec, Czech Republic, for the use of laboratory equipment and facilities, as well as for technical guidance in this project and the CSIR Materials Science and Manufacturing (National Fibre, Textile and Clothing Centre) in Port Elizabeth and specifically Ms Tando Mbanga (Clothing Technologist/Researcher) for the use of and assistance with the tests on WALTER ${ }^{\mathrm{TM}}$ thermal manikin. 


\section{INTRODUCTION}

A growing consumer demand for products that provide protection, are comfortable, and can be described as environmentally friendly has lead to much research and development in the textile industry of the utilisation of renewable and biodegradable resources, as well as environmentally sound manufacturing processes.

Bamboo viscose, also known as regenerated bamboo, is a regenerated cellulose fibre that has recently appeared on the market for textiles for apparel and home furnishings. Regenerated cellulosic bamboo fibre was first manufactured in 2002 in China by Hebei Jigao Chemical Fibre Co. Ltd. (Erdumlu \& Ozipek, 2008). Products from regenerated bamboo are suitable for a wide range of end-uses, such as towels, bathrobes, surgical clothes, bedding, food packaging and even hygiene products such as sanitary pads, surgical masks, bandages and mattresses. Bamboo viscose is however in a slightly higher price range than other cellulose fibres. It is marketed as having exceptional properties such as superior comfort and hand, as well as antimicrobial properties.

Promotional claims regarding regenerated bamboo fabrics (usually only referred to as "bamboo" fabrics) state that these fabrics have better moisture absorption and ventilation, can absorb and evaporate human sweat in a split second, have excellent comfort because of its high breathability and is soft, with a cooling effect on the skin in hot weather (Shanghai Tenbro Bamboo Textile Co., 2007). They even claimed that "bamboo fibers are $1-2^{\circ} \mathrm{C}$ lower in temperature than normal apparel in the hot summer." (No empirical data are given to prove this, and it is unclear whether the author referred to the fibers physically having a lower temperature, or whether it is merely a sensorial feeling or sensation.) Bamboo viscose fabrics are also promoted for their proposed antimicrobial properties, with promotional material claiming "particular and natural functions of antibacteria, bacteriostatis and deodorization" (China Bambro Textile Co. Ltd., 2003) and "inherent antimicrobial properties" (Swicofil AG Textile Services, 2007). Other claims include assumptions that regenerated bamboo products are " $100 \%$ bamboo fibre", "manufactured by using environmentally friendly processes" and are "biodegradable" (Bamboo claims discouraged, 2009).

Proof of official action against the use of unwarranted of unproven claims for commercial purposes came in 2009 when three companies marketing regenerated bamboo products were charged by the US Federal Trade Commission (FTC) in accordance with the Commission's Textile Fiber Products Identification Act and Rules. Subsequent settlements forbid these companies to continue making any claims "about the benefits, performance of efficacy of any clothing or textile product they sell, unless backed by reliable evidence" (Bamboo claims discouraged, 2009).

Bamboo is botanically categorized as a grass and not a tree. It is probably the world's most sustainable resource. Bamboo is the fastest growing grass, it can grow up to $119 \mathrm{~cm}$ in 24 hours and does not require replanting after harvesting due to the development of a vast root network. The inherent antimicrobial properties of bamboo eliminate the need for pesticides and fertilizers. Thereis no doubt that growing natural organic bamboo is significantly beneficial to the environment (Fu, 2001).

Contrary to the above, the manufacturing processes whereby the bamboo plant is transformed into bamboo yarns and fabric are where the sustainability and eco-friendly character of bamboo can be questioned.

Regenerated bamboo fibres are produced in a wetspun process in which natural cellulose (in this case originating from mechanically crushed bamboo leaves and stems) is used as raw material in a hydrolysisalkalisation process (Erdumlu \& Ozipek, 2008; Sui et al, 2003). The raw material is obtained from the Phylostachys heterocycla pubescens bamboo plant, commonly known as Moso bamboo (Fu, 2001)).

Bamboo fibre can also be manufactured via a mechanical process. First the woody parts of the bamboo plant are crushed and then natural enzymes are used to break the bamboo walls to form a soft mass, from which the natural fibers can be mechanically combed out and spun into yarn. The products are sometimes referred to as bamboo linen due to the similarity to the flax conversion process. This process is however seldom used because it is labour intensive and costly (Erdumlu \& Ozipek, 2008).

Cotton is the natural cellulosic fibre most widely used in apparel and home furnishing manufacturing due to its comfort (high absorbency) and anti-allergenic properties. Viscose rayon was the first regenerated cellulosic fibre and is still one of the main substitutes for cotton in these applications. Viscose rayon fibres are wet-spun from wood pulp in the viscose process, which is very similar to the process now used to produce regenerated bamboo fibres (where bamboo cellulose is used as raw material). Consequently, regenerated bamboo fibres are referred to as bamboo viscose. Erdumlu and Ozipek (2008) studied the properties of bamboo viscose and viscose rayon yarns and found that the yarn characteristics of the two fibre types are quite similar. The two processes used to spin respectively viscose rayon and regenerated bamboo fibres (also known as bamboo viscose) are briefly described in Table 1.

\section{Comfort in clothing}

Textile scientists describe comfort in clothing as a state where the wearer is unaware of his or her clothes both physiologically and psychologically (Hatch, 1993:27). Comfort in clothing can also be described as a subjective, sensorial feeling, but this is difficult to measure objectively ( $\mathrm{Li}, 1998)$. When a person becomes aware of his/her clothing, it is usually an indication of a state of discomfort, e.g. too hot, too cool, too wet or too prickly. Hatch (1993:27) refers to a central or "neutral" point as "comfortable". Any de- 
TABLE 1: A COMPARISON OF THE PROCESSES BY WHICH VISCOSE RAYON AND REGENERATED BAMBOO FIBRES/BAMBOO VISCOSE ARE SPUN (Erdumlu \& Ozipek, 2008; Kadolph \& Langford, 2002:81;Trotman, 1990:91-93; Wilkes, 2001:37-50)

\begin{tabular}{|c|c|c|}
\hline & Process used in the spinning of viscose rayon & Process used in the spinning of bamboo viscose \\
\hline Preparation & $\begin{array}{l}\text { Crude wood chips are treated by boiling with calcium bisul- } \\
\text { phate to dissolve the lignin and impurities. The resultant pulp } \\
\text { is bleached with sodium hypochlorite yielding solid sheets } \\
\text { comprising } 90-94 \% \text { pure cellulose. }\end{array}$ & $\begin{array}{l}\text { Bamboo leaves and the soft inner pith from a hard bamboo trunk } \\
\text { are extracted and mechanically crushed. }\end{array}$ \\
\hline Steeping & $\begin{array}{l}\text { Sheets are steeped in caustic soda, to convert the } \alpha- \\
\text { cellulose into alkali cellulose and dissolve the hemicelluloses. }\end{array}$ & $\begin{array}{l}\text {-Crushed bamboo cellulose is soaked in a solution of } 15-20 \% \\
\text { sodium hydroxide at } 20-25^{\circ} \mathrm{C} \text { for } 1-3 \mathrm{~h} \text { to form alkali cellulose. }\end{array}$ \\
\hline Pressing and shredding & $\begin{array}{l}\text { The alkali cellulose is pressed to remove excess sodium hydro } \\
\text { to increase the surface area, making the cellulose easier to pro }\end{array}$ & $\begin{array}{l}\text { roxide solution. The alkali cellulose sheets are shredded into crumbs } \\
\text { rocess. }\end{array}$ \\
\hline Ageing & $\begin{array}{l}\text { The shredded alkali cellulose is left to dry in contact with ox } \\
\text { partially oxidised and degraded to a lower molecular weight di } \\
\text { mer chain lengths short enough to produce the required correc }\end{array}$ & $\begin{array}{l}\text { xygen in the ambient air. During this process the alkali cellulose is } \\
\text { due to the high alkalinity. The degradation is controlled to yield poly- } \\
\text { ct viscosities in the spinning solution. }\end{array}$ \\
\hline Sulphurisation & After ageing, carbon disulphide is added to the alkali cellulose & to sulphurise the compound, causing it to gel. \\
\hline Xanthation & $\begin{array}{l}\text { The remaining carbon disulphide from the sulphurisation is } \\
\text { removed by evaporation, to afford sodium xanthate. }\end{array}$ & $\begin{array}{l}\text { The remaining carbon disulphide from the sulphurisation is re- } \\
\text { moved by evaporation, to afford cellulose sodium xanthogenate. }\end{array}$ \\
\hline Spinning & $\begin{array}{l}\text { After ageing, the solution is filtered and extruded through a } \\
\text { spinneret into a sulphuric acid bath where it solidifies, to form } \\
\text { viscose rayon filament fibres. } \\
\text { The formed filaments are washed with water to remove any } \\
\text { liquor or products left from the coagulation bath and then } \\
\text { immersed into a sodium sulphide solution to remove free } \\
\text { sulphur and sulphur-containing compounds formed during } \\
\text { precipitation. } \\
\text { The viscose rayon is marketed as filaments or cut into staple. } \\
\text { fibre. }\end{array}$ & $\begin{array}{l}\text { A diluted solution of sodium hydroxide is added to the cellulose } \\
\text { sodium xanthogenate, which dissolves it, to afford a viscose solu- } \\
\text { tion consisting of about } 5 \% \text { sodium hydroxide and } 7-15 \% \text { bamboo } \\
\text { fibre cellulose. After subsequent ripening, filtering and degassing, } \\
\text { the viscose bamboo cellulose is forced through spinneret nozzles } \\
\text { into a large container containing a diluted sulphuric acid solution, } \\
\text { which hardens the viscose bamboo cellulose sodium xanthate and } \\
\text { reconverts it into cellulose bamboo fibre filaments. These are cut } \\
\text { into staple fibres and spun into bamboo fibre yarns. }\end{array}$ \\
\hline
\end{tabular}

viation from this can be described as the degree of warmness or wetness away from the central point. Smith (1993) confirms that although positive comfort sensations can be perceived, negative comfort sensations are noticed more often. A state of "very comfortable" cannot be assessed (Hatch, 1993:27).

Li (2001) studied thermo-physiological comfort of clothing and defined it as the garment's ability to keep the wearer dry and to regulate body temperature during a change in the environmental temperature or humidity, and during physical activity, contributing to the thermal equilibrium of the body. Thermophysiological comfort is directly dependant on fabric moisture and thermal transfer properties. To keep the wearer comfortable and dry, fabric properties such as absorbency, water vapour permeability and water vapour resistance (referred to as moisture management properties) are important. Thermal comfort is influenced by textile fabric properties such as thermal resistance and thermal absorptivity ("thermal absorptivity" is a term commonly used in textile publications and research papers on thermal comfort, referring to the fabric property that pertains to thermal absorption as measured with the Alambeta and Permetest instruments, in other words meaning "thermal absorption ability") (Hes, 2008; Matusiak, 2010).

\section{Moisture transfer properties}

\begin{abstract}
Absorbency Cellulosic fibres are generally perceived as comfortable mainly due to their excellent ability to absorb water. A fibre absorbs water by allowing water molecules to penetrate into the less ordered, amorphous areas of its molecular structure. Different fibres thus absorb different amounts of water (Hatch, 1993:34). Fibres with lower polymer orientation and crystallinity have more amorphous regions to
\end{abstract}

accept water molecules (Hatch, 1993:94). Within the cellulose fibre family, viscose rayon, with its semicrystalline structure (composed of crystallites together with more or less disordered amorphous regions) and high number of hydroxyl groups along the polymer chains, has a higher moisture regain and absorbency than cotton, with its more crystalline structure (Hatch, 1993:183; Müller et al, 2000).

Although viscose rayon does not have a complex submicroscopic structure, recent studies have shown that the fibre structure exhibits a unique "skin" and "core", which is the result of chemical conditions in the spinning bath. The different structures of the two areas are reflected in their dyeing capacity. The different characteristics of the "skin" and "core" areas were investigated by Müller et al (2000) who found that the core of the fibre appear less dense than the skin. As the skin is only a few micrometers thick, this means that more water will be absorbed into the core of the fibre, transporting water away from the fibre surface. This would lead to the surface area maintaining a dry "hand" for longer after exposure to moisture. Unfortunately, no reports on similar analyses on the bamboo viscose fibre could be found.

Moisture can also be absorbed into the microstructure of the fibres, e.g. between the many fibrils on the fibre surface in cotton fibres (Hatch, 1993:166) or transported through a fabric or along the fibre surface by capillary action, referred to as wicking (Hatch, 1993:33). The surface of the viscose rayon fibre is characterised by tiny grooves, called striations, which is a result of the way the fibres coagulate during the spinning process. This slightly uneven surface contributes to the next-to-skin contact comfort properties (Hatch, 1993:183). This structure is similar to that 
observed in regenerated bamboo fibres (Yang et al, 2009).

According to their website, the Shanghai Tenbro Co. (2007) reports that scanning electron microscopy (SEM) images of "bamboo fibres" reveal an internal structure containing micro-gaps and micro-holes, giving the fibres the ability to absorb and evaporate human perspiration at a high rate. The image projected in the report is probably that of a bamboo fibre though, and the question should be asked if this structure is retained, unchanged, in the regenerated bamboo fibre.

Water vapour permeability The human body continuously produces insensible perspiration in the form of water vapour. The body's natural mechanism for cooling itself when overheating is through sensible perspiration in the form of liquid sweat. This is caused by strenuous activity or climatic conditions. Both of these have to be managed rapidly by the wearer's clothing in order to maintain the body's thermal regulation (Barker, 2002; Hatch, 1993:31-32). Evaporation of the liquid sweat requires heat. Body heat is used to evaporate the perspiration, resulting in the dissipation of the surplus heat and the cooling of the body (Hatch, 1993:32). However, if the water vapour cannot escape to the surrounding atmosphere then the relative humidity inside the clothing increases, causing a wet feeling on the skin, and leading to an uncomfortable sensation.

Also known as "breathability", water vapour permeability is defined as a fabric's ability to transport water vapour from the skin surface through the fabric to the external environment. Hatch (1993:33) defines water vapour permeability as "the rate at which water vapour diffuses through a fabric." This should occur spontaneously because of the vapour pressure gradient. The water vapour dissipates from the high vapour pressure region (humid body surface) to the lower vapour pressure region (drier external environment). The diffusion of water vapour occurs through fabric interstices and air spaces between the skin and the fabric (Hatch, 1993:32).

Water vapour resistance Water vapour permeability is indirectly related to water vapour resistance. The latter property can be described as the amount of resistance against the transport of water vapour through a fabric. Because water is an excellent conductor of heat, the thermal resistance of a garment will be directly influenced by the amount of moisture present in the fabric. Thus, the more water present in a fabric, due to either normal absorption from the air or as a result of the absorption of liquid water (e.g. perspiration), the higher the rate will be at which heat is conducted. Under standard atmospheric conditions, cotton is expected to hold 7 to $11 \%$ moisture (Kadolph \& Langford, 2002:39), viscose rayon 11,5 to 12,5\% (Kadolph \& Langford, 2002:83) and regenerated bamboo $13 \%$ (Shanghai Tenbro Bamboo Textile Co., 2007; Swicofil AG Textile Services, 2007). The amount of water present in a garment therefore plays a significant role in the degree of comfort that will be felt. Although a fabric with good absorption will initially increase comfort, a wet fabric touching the skin will create an unpleasant sensation.

\section{Thermal transfer properties}

Thermal resistance Thermal resistance is a measure of the resistance that a garment provides against heat loss from the body of the wearer to the external environment (Clulow, 1984). It is influenced by a combination of the thermal resistance provided by the clothing, by the layer of air between the skin and the clothing, and by the layer of air between the inner and outer surfaces of the fabric. The thermal resistance of a fabric is more or less proportional to the thickness of the fabric. Thermal resistance is measured in $\mathrm{m}^{2} \mathrm{~K} / \mathrm{W}$, and can be converted to "tog" or "clo". One tog can be defined as a temperature difference of $0.1^{\circ} \mathrm{C}$ between two surfaces caused by the heat flow of 1 Watt/ $\mathrm{m}^{2}$ (1 tog $\left.=0.1 \mathrm{~m}^{2} \mathrm{~K} / \mathrm{W}\right)$ (Hatch, 1993:31). Thermal resistance is also sometimes measured in clo (a unit of thermal insulation of clothes). One clo represents the amount of clothing required to keep a sitting man of average metabolic rate comfortable in an average indoor atmosphere at $21^{\circ} \mathrm{C}$ (Clulow, 1984).

Thermal absorptivity A 'warm-cool' feeling is the first sensation experienced when a human touches a fabric. This feeling is a result of heat exchange that takes place between the human hand and the fabric because of the temperature difference between the fabric surface and that of the human skin. This is referred to as thermal absorptivity. If the thermal absorptivity of a garment is high it can be expected to give a cooler feeling upon first contact (Hes, 2008; Oğlakcioğlu \& Marmarali, 2007; Pac et al, 2001).

\section{Objective evaluation of fabric comfort properties}

The objective evaluation of fabric comfort properties is extremely complex. Subjective responses through wear trials play an important role in providing responses that can be related back to instrumentally assessed physical fabric properties (Barker, 2002), but obtaining such responses can be costly and time consuming, and results tend to be lacking in accuracy and reproducibility. Therefore various forms of physical and simulative tests have been developed, and improved over the years, to assess comfort through the measurement of specific properties related to uncomfortable sensations (Fan \& Qian, 2004; Saville, 1999:209-230; Smith, 1993). Success has also been achieved with various tests simulating wearing conditions on different models of thermal and sweating manikins (Fan \& Qian, 2004).

WALTER $^{\text {TM }}$ sweating thermal manikin According to Fan and Qian (2004), the best simulative test involves the use of thermal manikins, but simulation of human perspiration remains a challenge. They are of the opinion that the Walter ${ }^{\mathrm{TM}}$ sweating thermal manikin (US patent $6,543,657$ ) offers great potential in terms of measurement accuracy during tests comprising the simulation of walking and perspiration on fully made-up garments. Measurements are made while 
the $172-\mathrm{cm}$ breathable fabric manikin is simulating walking at a speed of $0-5 \mathrm{~km} / \mathrm{h}$ or is in a stationary state. "Walter" achieves a body temperature distribution similar to that of a human by pumping water at body temperature $\left(37^{\circ} \mathrm{C}\right)$ from its centre to its extremities.

During testing, the manikin is dressed in a garment made from the test fabric. Sensors measuring temperature and humidity are placed on specific areas on the manikin and connected to a computer, which controls and monitors the rate of heat loss and perspiration. A photograph of the manikin in the test chamber is shown in Figure 1.

The Walter ${ }^{\mathrm{TM}}$ apparatus measures thermal resistance $\left(R_{t}\right)$, water vapour resistance $\left(R_{e t}\right)$ and absorbency of a garment and calculates the moisture permeability index $\left(I_{m}\right)$. Unlike many other manikins, Walter ${ }^{T M}$ measures the two most important parameters, thermal resistance and water vapour resistance, in only one step. The moisture permeability index is an overall indication of the thermo-physiological comfort, which is dimensionless. The moisture permeability index is calculated by the Walter ${ }^{\mathrm{TM}}$ software according to the following formula: $I_{m}=60.6 \times R_{t} / R_{e t}$

The water absorbency (\%) of the textile fabric, in other words, the amount of moisture accumulated in the fabric, is determined by weighing the conditioned garments before dressing the manikin $\left(\mathrm{W}_{\mathrm{b}}\right)$ and after removing the garments at the end of the procedure $\left(\mathrm{W}_{\mathrm{a}}\right)$, and calculated as follows: $M_{\mathrm{a}}(\%)=\left(\mathrm{W}_{\mathrm{a}}-\mathrm{W}_{\mathrm{b}}\right) / \mathrm{W}_{\mathrm{b}} \mathrm{X} 100$

According to Hes (1999 and 2008), a person becomes aware of his clothing within a very short time period after putting it on or experiencing a change in environmental conditions. Therefore, measuring thermal and moisture management properties within a short time frame will give a more realistic measurement of the fabric properties. Several test instruments have been developed specifically for this purpose, e.g. the Alambeta and Permetest instruments.

The Alambeta instrument This test instrument

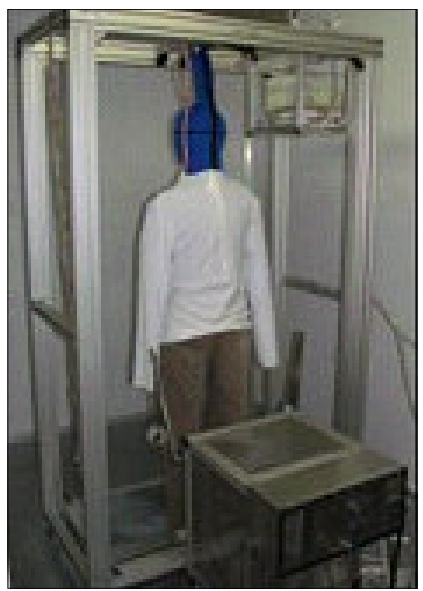

FIGURE 1: PHOTOGRAPH OF THE WALTER ${ }^{\text {TM }}$ SWEATING THERMAL MANIKIN

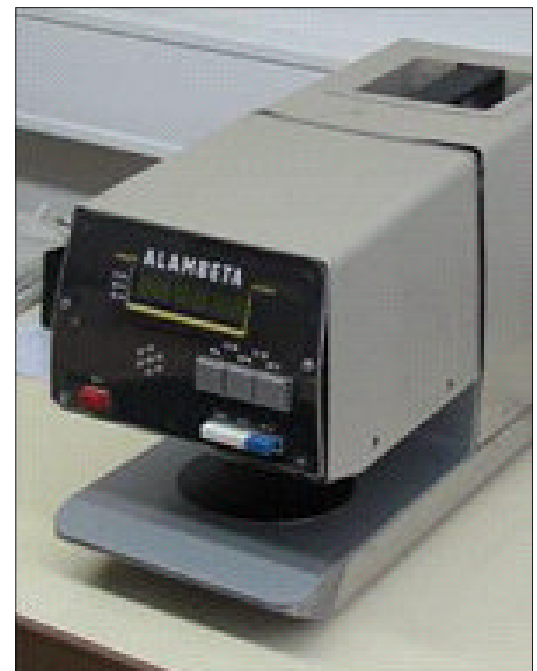

\section{FIGURE 2: PHOTOGRAPH OF THE ALAMBETA TEST INSTRUMENT}

was developed at the Technical University of Liberec (Czech Republic) for the objective evaluation of the thermal absorptivity of textile fabrics (Hes, 2008; Oğlakcioğlu \& Marmarali, 2007). The instrument is computer controlled, and uses the statistical parameters of measurements for thermal conductivity, thermal resistance and sample thickness to calculate the thermal absorptivity $\left(\mathrm{Ws}^{1 / 2} / \mathrm{m}^{2} \mathrm{~K}\right)$. An auto diagnostic program checks measurement precision to avoid any faulty instrument operation. The main advantage of this instrument is that the entire evaluation process takes less than three minutes to complete. Thermal absorptivity is regarded as an indication of the warmcool feeling that will be experienced upon touch (Hes, 2010; Oğlakcioğlu \& Marmarali, 2007). A photograph of the Alambeta instrument is shown in Figure 2.

The Permetest instrument The Permetest instrument is a semi-automated, portable, computercontrolled instrument, developed by Hes and manufactured by the Sensora Company in Liberec, Czech Republic. It was developed for the fast measurement of water vapour permeability (WVP) and resistance $(\mathrm{WVR})$ as well as thermal resistance $\left(\mathrm{R}_{\mathrm{t}}\right)$.

The instrument measures the amount of water vapour transmitted through a test sample, and the average WVP and WVR as well as the percentage coefficient of variance $(\mathrm{CV})$ are automatically calculated. The measurements are based on the principle of heat flux sensing. A fabric sample, $80 \mathrm{~mm}$ in diameter, is mounted on the machine against a highly sensitive measuring head, containing a highly sensitive heat flow sensor with a thermal inertia similar to that of the human skin. The sensors are able to distinguish very small changes in the amount of water absorbed by the fabric during unsteady state of diffusion and to record, for example, the heat of absorption. This results in high measurement repeatability, with CV often less than $3 \%$ (Hes, 2008; Hes 2010). The test is conducted under isothermal conditions; the temperature of the measuring head is maintained at room temperature. When water flows into the measuring head, 
some heat is lost due to evaporation. The instrument measures the evaporation of the "uncovered" head as well as that of the head when covered with the test fabric. The full test is completed when the transfer of water from the measuring head to the atmosphere reaches steady-state (usually within two to three minutes).

The relative WVP $(P)$ is a non-standardised, practical parameter and indicates the water vapour permeability of the tested sample as a percentage relative to that of a free measuring surface (where the WVP $=100 \%$ ). To calculate $P$, the ratio of heat loss from the measuring head with fabric $\left(q_{s}\right)$ and without fabric $\left(q_{0}\right)$ are used $\left(P=100\left[q_{1} / q_{0}\right] \%\right)$ (Das et al, 2008; Hes, 2008; Hes, 2010).

The water vapour resistance $\left(R_{\text {et }}\right)$ is expressed in $\mathrm{m}^{2} \mathrm{~Pa} / \mathrm{W}$ and thermal resistance $\left(\mathrm{R}_{\mathrm{t}}\right)$ in $\mathrm{m}^{2} \mathrm{~K} / \mathrm{W}$ as described in ISO standard 11092 (Hes,2010). A photograph of the Permetest instrument is shown in Figure 3.

\section{Problem statement}

Apart from the claimed "cool feeling", the comfort properties referred to in the promotion of bamboo viscose fabrics can generally be ascribed to most cellulose fibres or fabrics. Due to the smooth filament structure of viscose rayon, the fabric hand is also often described as smooth and luxurious, with excellent draping qualities, which could lead to a "cool" sensation when touched. The question of whether the

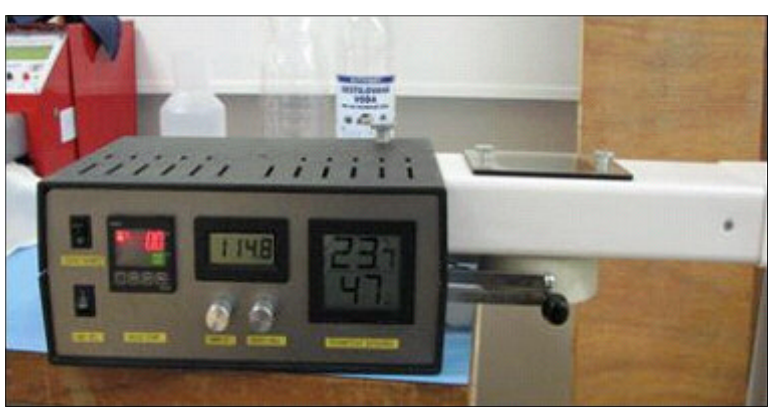

FIGURE 3: PHOTOGRAPH OF THE PERMETEST TEST INSTRUMENT
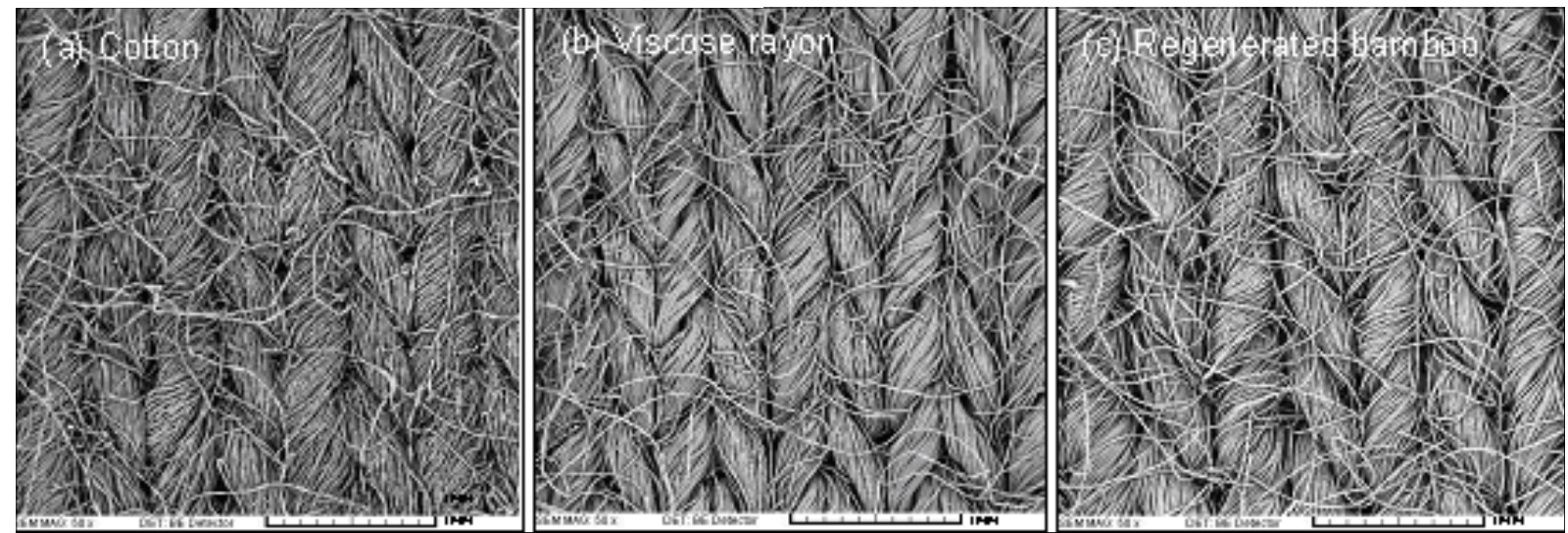

FIGURE 4: SEM FABRIC SURFACE IMAGES (50X MAGN.) OF COTTON, VISCOSE RAYON AND THE REGENERATED BAMBOO TEST FABRICS, RESPECTIVELY 


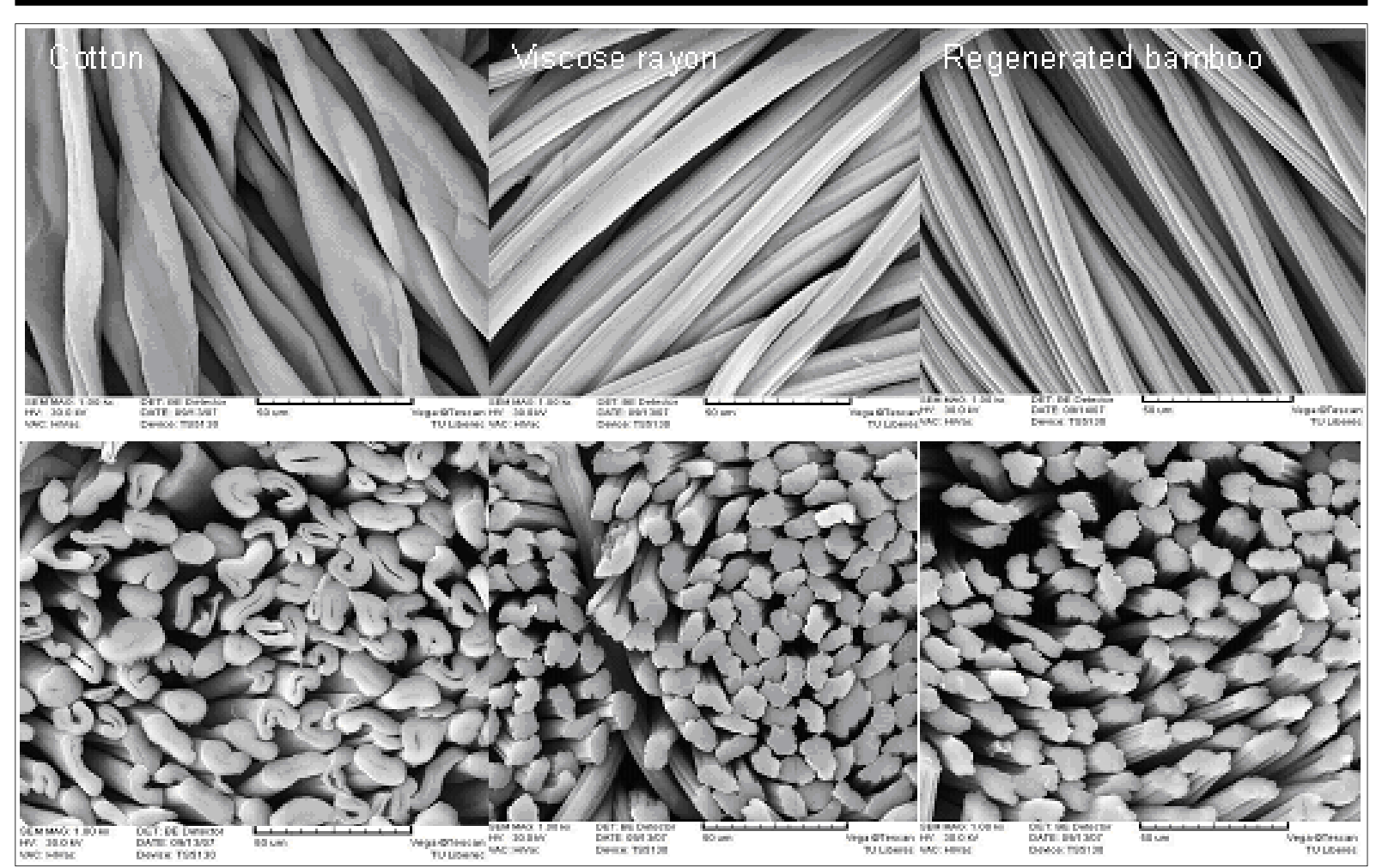

FIGURE 5: SEM IMAGES OF COTTON, VISCOSE RAYON AND REGENERATED BAMBOO FIBRES SHOWING THE LONGITUDINAL VIEW AT 500X MAGNIFICATION (TOP AND CROSSSECTIONAL VIEW AT 1000X MAGNIFICATION (BOTTOM)

Before testing, the samples were analysed according to fabric weight, gauge and thickness, to confirm comparability. All fabrics were fully conditioned according to SABS 70 prior to analyses. The fabric weight for each of the three fabric samples was measured using SABS Test Method 78. The average weight for the three samples was $169 \mathrm{~g} / \mathrm{m}^{2}$. The gauge was determined according to SABS Test Method 1120-1988. The average gauge was 14 wales and 17 courses per centimetre. The thickness of the three fabric samples was measured using the Uni-thickness measuring device at the University of Liberec, Czech Republic. An average of $0,487 \mathrm{~mm}$ was calculated, with not one deviating more than $0.02 \mathrm{~mm}$ from the average. Although small variations in thickness were found among the samples, the results of the measurements of fabric weight, gauge and sample thickness were considered comparable. None of the individual measurements varied by more than $10 \%$ from the average (which is considered normal for a sensitive fabric such a single jersey). To confirm comparability, SEM images of the fabric surfaces were inspected at 50 times magnification. These are shown and compared in Figure 4.

To compare the structure of the regenerated bamboo fibre with that of cotton and viscose rayon fibres, the longitudinal character and cross-section of fibres were studied using SEM.

Walter ${ }^{\mathrm{TM}}$ tests Tests on the sweating thermal manikin (Walter ${ }^{\mathrm{TM}}$ ) were carried out in the research laboratories at the CSIR in Port Elizabeth. Two long sleeved T-shirts were made up of each of the three fabric samples according to the specific measurements of the Walter ${ }^{\mathrm{TM}}$ manikin. The tests were performed at an ambient temperature of $25^{\circ} \mathrm{C}$, a relative humidity of $35 \%$ and a wind velocity of $<0.5 \mathrm{~m} / \mathrm{s}$ in the testing chamber, with the manikin dressed in the shirt and basic $100 \%$ cotton pants without a belt. The skin temperature of the manikin was kept at $37^{\circ} \mathrm{C}$. The T-shirts were conditioned at standard atmospheric conditions for 24 hours prior to testing, and the weight of each shirt was recorded before conditioning, after conditioning (before testing) and after testing. From this the water absorbency was calculated. One test cycle took 10 hours to complete, during which time the computer recorded hourly measurements for thermal resistance and water vapour resistance. From this moisture permeability index was calculated.

Alambeta and Permetest tests Thermal resistance and water vapour resistance were measured on the specialised Alambeta and Permetest instruments, respectively, at the Technical University of Liberec, Czech Republic. In all cases the samples were first conditioned for 24 hours under standard atmospheric conditions to ensure comparability at the time of testing. On each sample, five repeats were conducted on the Alambeta and three on the Permetest instruments. These numbers of repeats were considered sufficient for the tests (Hes, 2008).

A separate analysis of variance (ANOVA) was done on each set of results to determine the significance of the results. 
TABLE 2: WALTER ${ }^{\text {TM }}$ OBJECTIVE MEASUREMENTS FOR THERMAL RESISTANCE, WATER VAPOUR RESISTANCE, WATER ABSORBENCY AND TOTAL MOISTURE PERMEABILITY INDEX

\begin{tabular}{|l|c|c|c|c|}
\hline & $\begin{array}{c}\text { Thermal resistance }\left(\mathbf{R}_{\mathbf{t}}\right) \\
\left(\mathbf{m}^{2} \mathbf{K} / \mathbf{W}\right)\end{array}$ & $\begin{array}{c}\text { Water vapour resistance }\left(\mathbf{R}_{\mathrm{et}}\right) \\
\left(\mathbf{m}^{2} \mathrm{~Pa} / \mathrm{W}\right)\end{array}$ & $\begin{array}{c}\text { Water absorbency } \\
\%\end{array}$ & $\begin{array}{c}\text { Moisture permeability index } \\
\left(\mathbf{I}_{\mathbf{m}}\right)\end{array}$ \\
\hline Cotton & 0,171 & 21.25 & 1.90 & 0.49 \\
\hline Regenerated bamboo & 0.181 & 21.19 & 2.16 & 0.52 \\
\hline Viscose rayon & 0.189 & 20.74 & 2.02 & 0.55 \\
\hline
\end{tabular}

\section{RESULTS AND DISCUSSION}

To compare the $100 \%$ regenerated bamboo, $100 \%$ viscose rayon and $100 \%$ cotton fabrics with regard to properties related to moisture management and thermo-physiological comfort, samples were tested on the Walter $^{\mathrm{TM}}$ sweating thermal manikin and on two instruments, the Permetest and Alambeta. When interpreting the results obtained, it is important to note that these tests fall in two different 'categories' due to the differences between the experimental conditions on which they are based. Walter ${ }^{\mathrm{TM}}$ measurements are taken hourly over a 10 hour period in an atmospherically controlled chamber, where the temperature of the manikin $\left(37^{\circ} \mathrm{C}\right)$ differs from the surroundings $\left(25^{\circ} \mathrm{C}\right)$, to simulate wearing conditions. Permetest and Alambeta measurements are carried out over a short time period $(3 \mathrm{~min})$ under controlled isothermal conditions.

\section{Physical structure of fibres}

SEM images were used to compare the physical structures of the three test fabrics on microscopic scale to determine if any differences were noticeable that could explain test results. Images of the regenerated bamboo, cotton and viscose rayon fibres, taken at 500X and 1000X magnification, are shown in Figure 5. No indication of micro-holes could be found at these magnifications. Distinct differences were noticeable between the cotton and the two regenerated fibres, but the similarities between the latter two were obvious. Both the viscose rayon and regenerated bamboo fibres have distinct lengthwise lines, or striations, and serrated cross-sections, with an indented circular shape.

The above confirmed allegations made in literature that regenerated bamboo is actually technically viscose rayon (Bamboo claims discouraged, 2009). It also explains the smoother and more luxurious hand of the viscose rayon and regenerated bamboo fabrics in comparison to the cotton fabric. It gives no indication though that superior sensorial or thermophysiological comfort properties could be expected of the regenerated bamboo when compared to the viscose rayon fabric.

\section{Thermo-physiological properties}

The results were discussed according to the main aim, namely the comparison of thermo-physiological properties (moisture and thermal transfer).

To compare the overall thermo-physiological comfort of the three test fabrics, results from the tests on the sweating thermal manikin $\left(\right.$ Walter $^{\mathrm{TM}}$ ) were used to calculate the moisture permeability index of each.
Results for thermal resistance and moisture management properties, such as water vapour resistance and water absorbency, obtained under conditions simulating the fabric behavior over a 10 hour period, were subsequently compared individually. Results are summarized in Table 2.

To test the significance of the differences between the fabrics statistically, ANOVAs were carried out on all the individual measurements. In none of the cases could any of the differences be proved significant at a $95 \%$ confidence level. The comparison with regard to the moisture permeability index is shown in Figure 6. Results for the thermal resistance are depicted

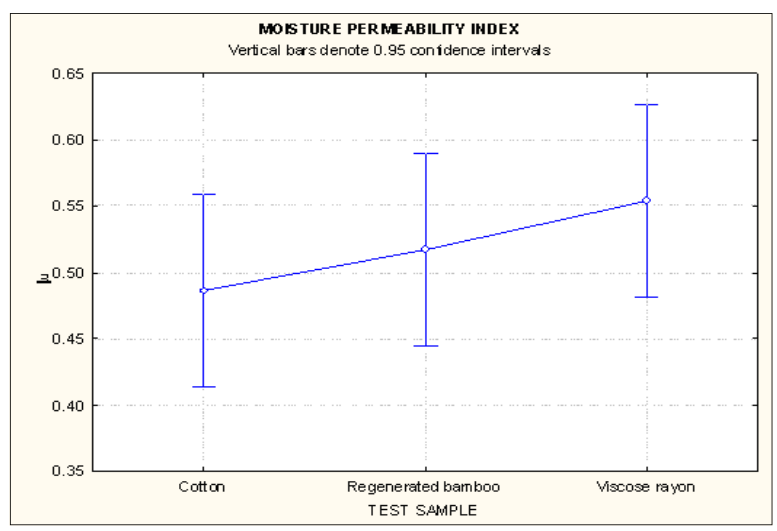

FIGURE 6: COMPARISON OF THE AVERAGE MOISTURE PERMEABILITY INDEX OF $100 \%$ COTTON, $100 \%$ REGENERATED BAMBOO AND $100 \%$ VISCOSE RAYON FABRIC SAMPLES MEASURED ON WALTER ${ }^{\text {TM }}$

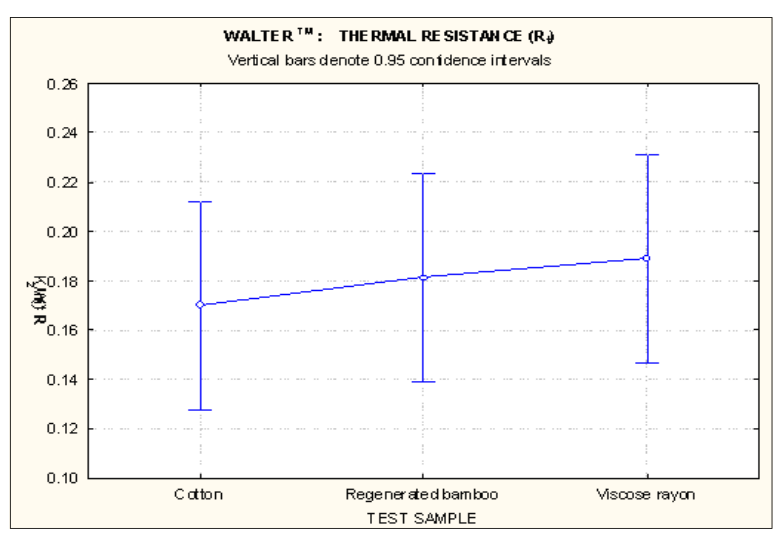

FIGURE 7: COMPARISON OF WALTER ${ }^{\text {TM }}$ RESULTS FOR THE AVERAGE THERMAL RESISTANCE OF $100 \%$ COTTON, $100 \%$ REGENERATED BAMBOO AND $100 \%$ VISCOSE RAYON FABRICS 


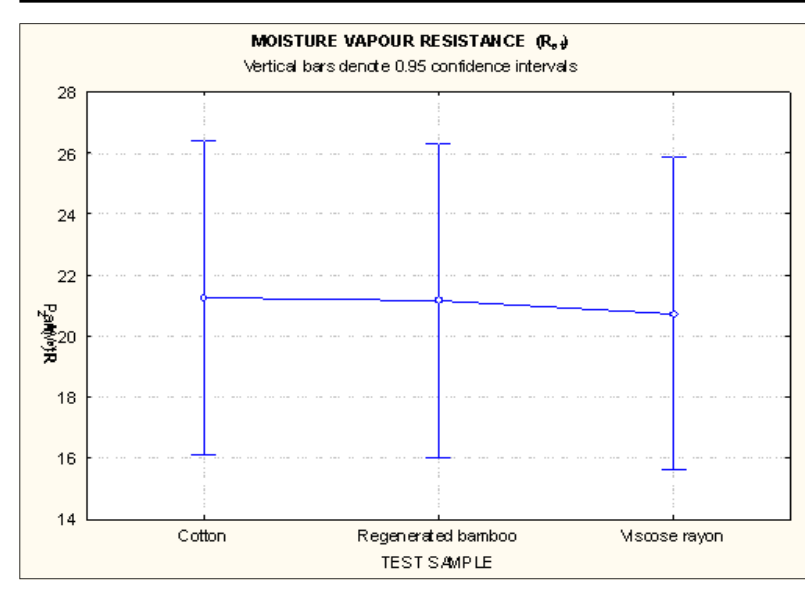

FIGURE 8: COMPARISON OF WALTER ${ }^{\text {TM }}$ RESULTS FOR THE AVERAGE WATER VAPOUR RESISTANCE OF $100 \%$ COTTON, $100 \%$ REGENERATED BAMBOO AND $100 \%$ VISCOSE RAYON FABRICS

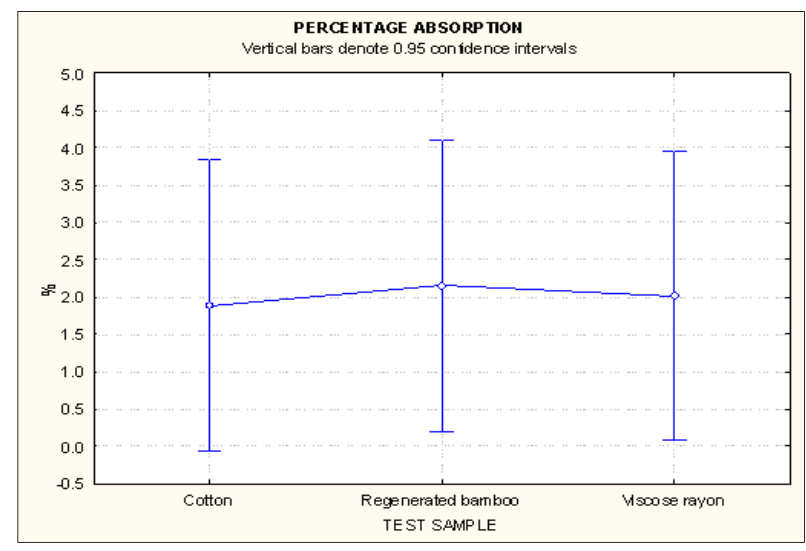

FIGURE 9: COMPARISON OF WALTER ${ }^{\text {TM }}$ RESULTS FOR THE AVERAGE ABSORBENCY (\%) OF $100 \%$ COTTON, $100 \%$ REGENERATED BAMBOO AND $100 \%$ VISCOSE RAYON FABRICS

graphically in Figure 7 and those for water vapour resistance and water absorbency in Figures 8 and 9, respectively.

The graphic images confirmed that, according to these test results, the regenerated bamboo fabric was not superior to the other two cellulosic fabrics with regard to its ability to thermally insulate body heat nor with regard to moisture management properties, such as the ability to allow water vapour to escape through the fabric or to absorb liquid water from a wet skin. This was confirmed by the calculated moisture permeability index for each of the respective fabrics. Although Figure 6 indicates that the average water vapour permeability index value for the viscose rayon fabric was slightly higher than that of the other two fabrics, this could not be proved as statistically significant. What it did confirm undisputedly is that the regenerated bamboo failed to outperform the viscose rayon and cotton fabrics.

Moisture transfer Further tests to measure the wa- ter vapour resistance $\left(R_{\text {et }}\right)$, also referred to as absolute water vapour permeability, and water vapour permeability $(P)$ of the fabrics were carried out on the Permetest instrument. Results are summarized in Table 3. The average water vapour resistance $\left(R_{\mathrm{et}}\right)$ was $5.9 \mathrm{~Pa} . \mathrm{m}^{2} . \mathrm{W}^{-1}$ for the regenerated bamboo, 5.6 $\mathrm{Pa} . \mathrm{m}^{2} . \mathrm{W}^{-1}$ for the viscose rayon and 6.0 Pa. $\mathrm{m}^{2} . \mathrm{W}^{-1}$ for the cotton fabric and water vapour permeability $(P)$ was $36.6 \%, 35.5 \%$ and $36.1 \%$, for the same fabrics, respectively. An ANOVA on the Permetest results confirmed that the small differences between the averages for the three fabrics are not significant. The Permetest results are shown graphically in Figure 10. The moisture transfer properties measured on the Permetest instrument confirms the trend found in the results from the Walter ${ }^{\mathrm{TM}}$ (Figure 6). It is clear that the differences found among the three test fabrics are not significant.

Thermal transfer To compare the thermal transfer properties, thermal resistance and sample thickness were measured and thermal absorptivity calculated on the Alambeta instrument. The results are summarized in Table 4 and depicted graphically in Figure 11 (a), (b) and (c).

Thermal resistance is closely related to the thickness of the fabric (Hatch, 1993:31; Oğlakcioğlu \& Marmarali, 2007). When measuring the thermal resistance of a fabric it is important that the sample thickness is taken into account. The original thickness measurements of the three fabrics that were tested were comparable under relaxed conditions. However, Alambeta measurements are recorded under conditions where the sample is under a pressure of $2 \mathrm{kPa}$. This eliminates the effect of excess trapped air in the fabric structure. Data from the Alambeta indicated that this lead to a difference in the thickness of the fabrics tested: the regenerated bamboo and cotton samples measurements differed very little, but the viscose rayon was thinner. Using the Alambeta values, the thermal resistance measurements were adjusted according to the sample thickness to make it comparable. The adjusted thermal resistance of the three fabrics was compared in Figure 11(b).

Regenerated bamboo, viscose rayon and cotton fabrics are mainly used for summer clothing. A lower thermal resistance would thus be an advantage in these fabrics - allowing body heat to escape through the fabric to the environment and to keep the wearer cooler. All the fabrics tested had relatively low thermal resistances, with that of the regenerated bamboo being (contrary to the expectation) slightly higher than the others, even after adjustments were made to allow for differences in sample thickness. Statistical analyses confirmed that the differences among the samples were not significant at a $95 \%$ confidence level, confirming the findings on the Walter ${ }^{\mathrm{TM}}$ shown in Figure 7. (The differences in $R_{t}$ values shown in Figures 7 and $11(\mathrm{a})$ and $11(\mathrm{~b})$ are due to the different principles of measurement on the two instruments, as explained earlier.)

In order to compare the so-called "cool feeling" experi- 


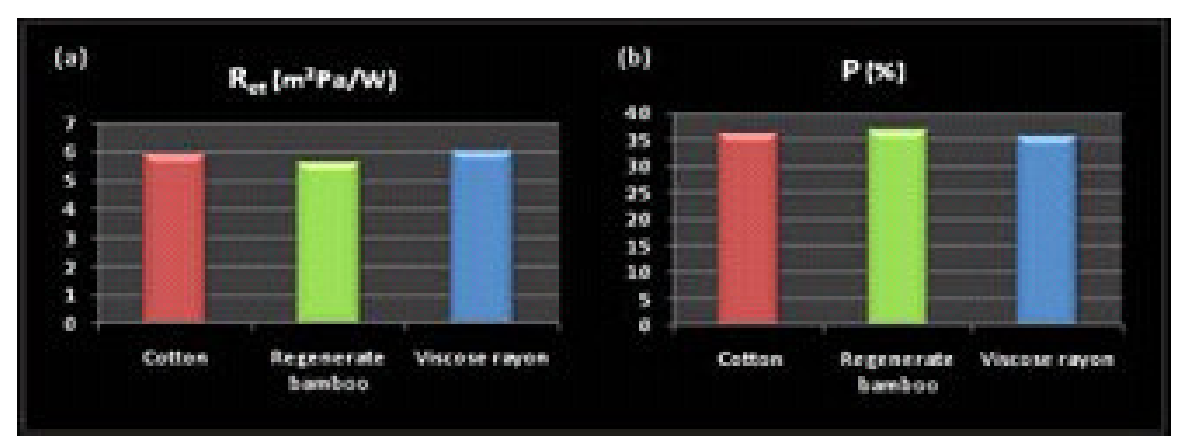

FIGURE 10: COMPARISON OF PERMETEST RESULTS FOR AVERAGE WATER VAPOUR RESISTANCE $\left(\mathrm{m}^{2} \mathrm{~Pa} / \mathrm{W}\right)$ AND \% WATER VAPOUR PERMEABILITY (P) OF COTTON, REGENERATED BAMBOO AND VISCOSE RAYON FABRICS

TABLE 3: TABLE 3: PERMETEST RESULTS FOR WATER VAPOUR PERMEABILITY AND WATER VAPOUR RESISTANCE (ABSOLUTE WATER VAPOUR PERMEABILITY (CV = COEFFICIENT OF VARIATION)

\begin{tabular}{|l|c|c|c|c|}
\hline & $\begin{array}{c}\text { Relative water vapour permeability } \\
\mathbf{P ( \% )}\end{array}$ & $\mathbf{C V}(\%)$ & $\begin{array}{c}\text { Water vapour } \\
\text { resistance } \\
(\mathbf{m} 2 \mathrm{~Pa} / \mathrm{W})\end{array}$ & $\begin{array}{c}\mathrm{CV} \\
(\%)\end{array}$ \\
\hline Cotton & 36.1 & 2.2 & 5.9 & 4.8 \\
\hline Regenerated bamboo & 36.6 & 3.6 & 5.6 & 4.8 \\
\hline Viscose rayon & 35.5 & 5.4 & 6.0 & 7.5 \\
\hline
\end{tabular}

TABLE 4: $\quad$ SUMMARY OF RESULTS FROM THE ALAMBETA TESTS

\begin{tabular}{|l|c|c|c|c|}
\hline & $\begin{array}{c}\text { Thermal conductivity } \\
\left(\mathbf{W} / \mathbf{m}^{2} \mathbf{K}\right)\end{array}$ & $\begin{array}{c}\text { Thermal absorptivity } \\
\left(\mathbf{W s}^{\mathbf{1} / 2} / \mathbf{m}^{2} \mathbf{K}\right)\end{array}$ & $\begin{array}{c}\text { Thermal resistance }\left(\mathbf{R}_{\mathrm{t}}\right) \\
\left(\mathbf{m}^{2} \mathbf{K} / \mathbf{W}\right)\end{array}$ & $\begin{array}{c}\text { Sample thickness } \\
(\mathbf{m m})\end{array}$ \\
\hline Cotton & 54.1 & 167 & 9.0 & 0.49 \\
\hline Regenerated bamboo & 50 & 171 & 10.6 & 0.53 \\
\hline Viscose rayon & 51.9 & 212 & 8.0 & 0.42 \\
\hline
\end{tabular}

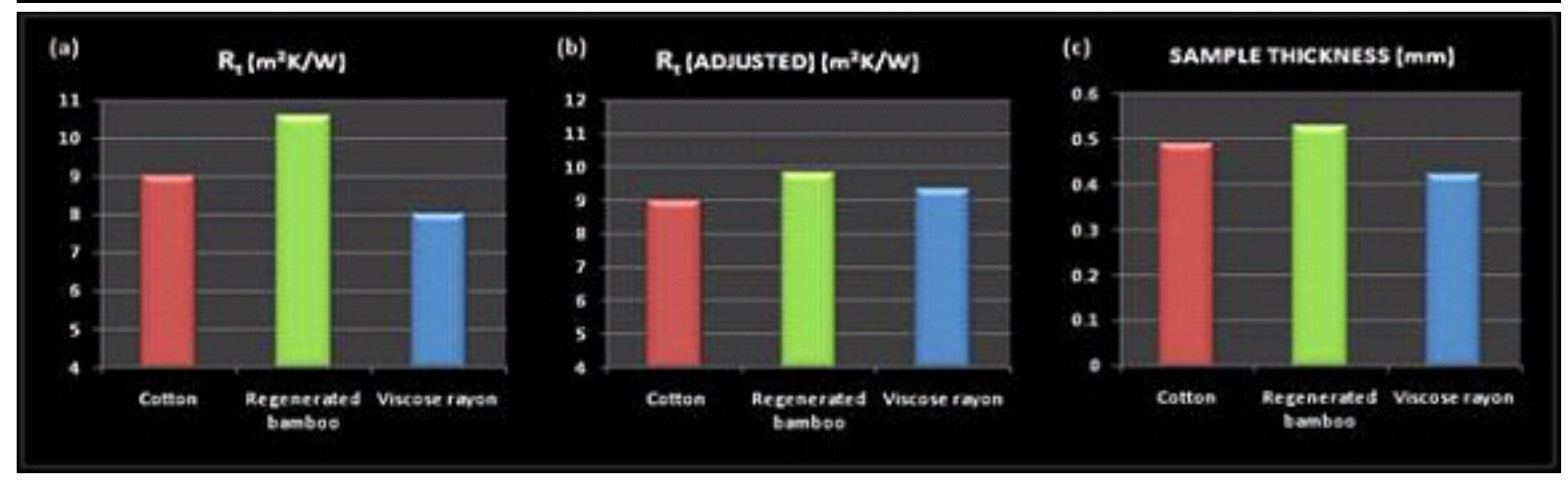

FIGURE 11: COMPARISON OF ALAMBETA RESULTS, SHOWING (a) THERMAL RESISTANCE $\left(\mathrm{m}^{2} \mathrm{KW}\right)$, (b) THERMAL RESISTANCE ADJUSTED TO ALLOW FOR DIFFERENCES IN SAMPLE THICKNESS AND (c) SAMPLE THICKNESS (mm) OF COTTON, REGENERATED BAMBOO AND VISCOSE RAYON FABRICS

enced when a fabric is touched, the thermal absorptivity values were also compared. To substantiate the claim that regenerated bamboo feels cooler to the touch, the thermal absorptivity of the tested sample should be higher than those of the others (Hes, 2008; Oğlakcioğlu \& Marmarali, 2007; Pac et al, 2001). This was not the case for the samples tested. Figure 12 shows that the results for the cotton and regenerated bamboo fabrics were very close (171 and $167 \mathrm{Ws}^{1 / 2}$ ) $\left.\mathrm{m}^{2} \mathrm{~K}\right)$, while that of the viscose rayon was higher (212 $\left.\mathrm{Ws}^{1 / 2} / \mathrm{m}^{2} \mathrm{~K}\right)$. The Alambeta thickness measurements (Figure 11(c)) showed that the viscose rayon samples were almost $20 \%$ thinner than the averages of the regenerated bamboo and cotton fabrics - explaining the difference. What is important to note here though is that no indication could be found that the regenerated bamboo fabric exhibited a higher thermal absorptivity when compared to the cotton and viscose rayon fabrics.

\section{CONCLUSION}

Contrary to the expectations created around the new regenerated bamboo fibres, no empirical evidence was found in this study, when properties pertaining to comfort were compared, to confirm that regenerated bamboo fibres are superior to cotton and viscose rayon fibres. It should be noted though that none of the claims made were proven false - regenerated bamboo fibres can be made into fabrics that are very 
comfortable and have excellent moisture and temperature management properties. The results of physical tests on other cellulosic fibre fabrics, indicated, however, that the knitted cotton and the viscose rayon fabrics are comparable with regards to properties pertaining to comfort. Although not always statistically significant, it was clear that in many cases the performance of the viscose rayon in terms of comfort properties was closer to that of the regenerated

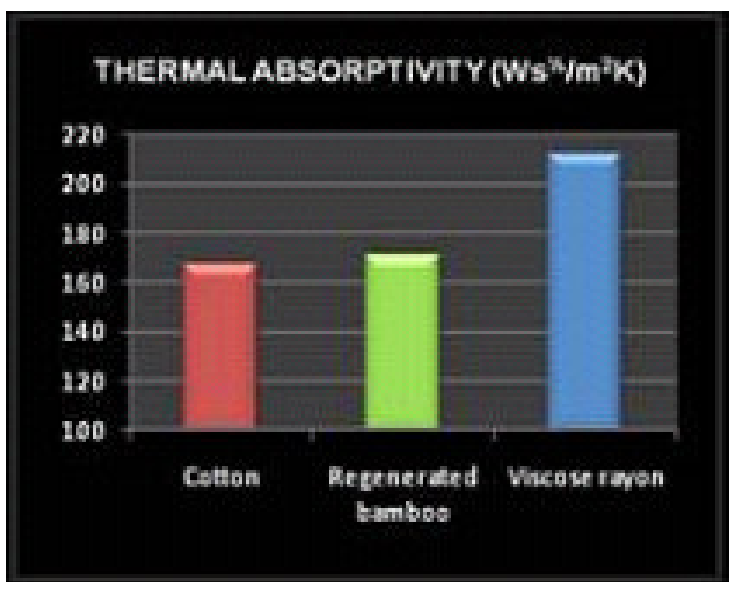

FIGURE 6: COMPARISON OF ALAMBETA RESULTS, SHOWING THERMAL ABSORPTIVITY OF COTTON, REGENERATED BAMBOO AND VISCOSE RAYON FABRICS

bamboo than to that of the cotton fabric. This confirmed earlier speculation that the regenerated bamboo would have very similar properties to viscose rayon because of the similarities in their production processes.

As was mentioned, the tests that the fabrics were subjected to fall in two different categories due to the differences between the experimental conditions on which they are based. In the one category (tests on the WALTER ${ }^{\mathrm{TM}}$ sweating manikin) measurements are taken hourly over a 10 hour period in an atmospherically controlled chamber with the temperature of the manikin $\left(37^{\circ} \mathrm{C}\right)$ differing from the surroundings $\left(25^{\circ} \mathrm{C}\right)$, to simulate wearing conditions. In the second category (the Permetest and Alambeta test instruments) measurements are carried out over a short time period (3 $\mathrm{min}$ ) under controlled isothermal conditions. The range of tests used in this study was specifically selected to cover both these categories, to ensure a comprehensive comparison of the fabric properties. The question pertaining to which of the two principles is most representative of actual wearing conditions is part of an ongoing debate and probably a topic for further research. What is important to note in the results obtained though, is that the three fabrics performed similarly in both categories, confirming the conclusion that no empirical evidence could be found that the regenerated bamboo fibre fabric is better than any one of the other two cellulose fabrics with regard to thermal and moisture management properties.

\section{REFERENCES}

BARKER, RL. 2002. From fabric hand to thermal comfort: the evolving role of objective measurements in explaining human comfort response to textiles. International Journal of Clothing Science and Technology 14(3/4):181-200.

BAMBOO FIBRE CLAIMS DISCOURAGED. 2009. Textile Horizons September-October:2009:20

CHINA TEXTILE CO., LTD. 2003 Experience the unparalleled advantages of bamboo fiber and bamboo yarn! [online] available: http://www.bambrotex.com. Accessed 31 October 2007.

CLULOW, E. 1984. Comfort indoors. Textile Horizons September:1984:20-22.

DAS, B, KOTHARI, VK, FANGUIERO, $R$ \& DE ARAÚJO, $M$. 2008. Effect of fibre diameter and cross-sectional shape on moisture transmission through fabrics. Fibres and Polymers 9(2):225231.

ERDUMLU, N \& OZIPEK, B. 2008. Investigation of regenerated bamboo fibre and yarn characteristics. Fibres and Textiles in Eastern Europe 16(4):43-47.

FAN, J \& QIAN, X. 2004. New functions and applications of Walter, the sweating fabric manikin. European Journal of Applied Physiology 92:641-644.

FU, J. 2001. Chinese Moso Bamboo: Its Importance. The Journal of The American Bamboo Society 22(5):5-6

HATCH, KL. 1993. Textile Science. New York. West Publishing Company.

HES, L. 1999. Optimization of shirt fabrics composition from the point of view of their appearance and thermal comfort. International Journal of Clothing Science and Technology 11(2/3):105115

HES, L. 2008. (personal communication March 17, 2008). Professor in Textile Science: Technical University of Liberec, Czech Republic.

HES, L. 2010. The use of comfort parameters in marketing of functional garments and clothing. Research paper presented at the $2^{\text {nd }}$ International Conference on Intelligent Textiles and Mass Customization. Casablanca. November 2010.

KADOLPH, SJ \& LANGFORD, AL. 2002. Textiles. $9^{\text {th }}$ ed. Upper Saddle River, New Jersey. Pearson Education.

LI, Y. 1998. Clothing comfort and its application. Textile Asia 29 July.

LI, Y. 2001. The science of clothing comfort. Textile Progress 31 (1): $1-135$

MATUSIAK, M. 2010. Structure versus thermal insulation properties of fabrics. Research paper presented at the Autex $201010^{\text {th }}$ World Textile Conference. Vilnius, Lithuania. June 2010.

MÜLLER, M, RIEKEL, R, VUONG, R \& CHANZY, H, 2000. Skin/ core micro-structure in viscose rayon fibres analysed by $\mathrm{X}$-ray microbeam and electron diffraction mapping. Polymer 41:26272632

OĞLAKCIOĞLU, N \& MARMARALI, A. 2007. Thermal comfort properties of some knitted structures. Fibres and Textiles in Eastern Europe 15(5):64-65.

PAC, MJ, BUENO, MA, RENNER, M \& EL KASMI, S. 2001.

Warm-cool feeling relative to tribological properties of fabrics. Textile Research Journal 71(9):806

SAVILLE, BP. 1999. Physical testing of textiles. Cambridge. Woodhead Publishing Limited.

SENSORA INSTRUMENTS \& CONSULTING. 2008. Information sheet on Permetest instrument. Reg. No.18330681. Na Výbezku 312, 46015 Liberec, Czech Republic.

SHANGHAI TENBRO BAMBOO TEXTILE CO. LTD. [online] available: http://www.Tenbro.com/en/green02.asp. Accessed 28 March 2007.

SMITH, JE. 1993. The comfort of clothing. Textiles 22(1):18-20.

SUI, S, ZHU, P, SUN, B \& LI, R. 2003. Exploring on microstructure and some properties of bamboo fiber. Qingdoa University, College of Chemical Engineering, P.R. China.

SWICOFIL AG TEXTILE SERVICES. [online] available: http:// www.swicofil.com/bambrotexantibacteria.html. Accessed 28 March 2007.

TROTMAN, E.R. 1990 (reprinted). Dyeing and chemical technology of textile fibers. $6^{\text {th }}$ ed. London. Charles Griffin.

WILKES, A.G. 2001. Regenerated Cellulose Fibers. Cambridge. Woodhead.

YANG, G, ZHANG, Y, SHAO, H \& HU, X. 2009. A comparative study of bamboo lyocell fiber and other regenerated cellulose fibres. Holzforschung 63:18-22. 